\title{
Strategi Korea Selatan dalam Pemulihan Krisis Moneter Tahun 1997 Melalui IMF
}

\author{
Yola Natasyah Kaloka, Putri Tegar, M. Eldy \\ Program Studi Hubungan Internasional, Universitas Muhammadiyah Malang - Indonesia \\ Email: natasyahkaloka3@gmail.com \\ Diserahkan: 20 April 2019 | Diterima: 29 April 2019
}

\begin{abstract}
During the monetary crisis in 1997, South Korea's economic growth increased the recession. This is due to a large amount of foreign money made by the maturing Chaebol. Add to that by reducing South Korea's very significant export revenue paid to the country's foreign exchange reserves. In line with this, it could lead to distrust of foreign creditors, so they withdrew funds that had planted in large-scale investment agreements several years earlier. Over time, South Korea could no longer run economic turmoil. How to improve the Government to collaborate with the IMF on November 21, 1997, as an effort to stabilize national finance, with total funding of US $\$ 57$ billion. In accordance with the role of the IMF, it means that South Korea has approved the procedures provided by the IMF that participated in the intervention of its national political economy. This paper will explained how the role of the IMF as an institutional liberal institution in South Korea, what forms of intervention carried out by the IMF, and how South Korea has utilized IMF assistance in its national economic recovery strategy.
\end{abstract}

Keywords: IMF, South Korea, Monetary, Crisis, Liberal, Institutions.

\begin{abstract}
Abstrak
Pada saat krisis moneter pada tahun 1997, pertumbuhan perekonomian Korea Selatan mengalami resesi. Hal Ini diakibatkan oleh banyaknya utang luar negeri yang dilakukan oleh Chaebol yang jatuh tempo. Ditambah lagi dengan penurunan pendapatan hasil ekspor Korea Selatan yang sangat signifikan yang berpengaruh pada cadangan devisa negara. Sejalan dengan hal tersebut, dapat mengakibatkan ketidakpercayaan kreditur luar negeri, sehingga mereka menarik kembali dana yang sudah di tanam dalam perjanjian Investasi besar- besaran beberapa tahun sebelumnya. Seiring berjalannya waktu, Korea Selatan tak sanggup lagi menghadapi gejolak ekonomi. Sehingga memaksa Pemerintah untuk menggandeng IMF pada 21 November 1997 sebagai ikhtiar menstabilkan perekonomian nasional, dengan dana bantuan total US\$ 57 miliar. Seiring dengan adanya peran IMF, artinya Korea Selatan diwajibkan mengikuti prosedur yang diberikan oleh IMF yang mengarah pada adanya intervensi ekonomi politik nasionalnya. Dalam tulisan ini akan dijelaskan bagaimana peran IMF sebagai lembaga liberalisme institusional di Korea Selatan, apa saja bentuk intervensi yang dilakukan oleh IMF, serta bagaimana Korea Selatan memamfaatkan bantuan IMF dalam strategi pemulihan ekonomi nasionalnya.
\end{abstract}

Kata Kunci: IMF, Korea Selatan, Moneter, Krisis, Liberal, Institusional.

\section{PENDAHULUAN}

\author{
Perekonomian Korea Selatan \\ sebenarnya cukup baik sebelum \\ terjadinya krisis ekonomi makro. Pada
}

September 1993, Bank Dunia
memberi predikat Korea Selatan
sebagai salah satu "Keajaiban Asia" 
bersama Jepang dan Indonesia (CNN, 2018). Korea Selatan adalah salah satu negara dengan kekuatan ekonomi dengan pertumbuhan tercepat di dunia, dengan tingkat pertumbuhan rata-rata 7 hingga $9 \%$ per tahun (Kihwan, 1999). Hal ini juga dapat dilihat pada dekade tahun 1990-an, ekonomi Korea Selatan tumbuh secara mengesankan yang dibuktikan dengan tingkat pertumbuhan ekonomi pada tahun 1995 yang mencapai 8,9\% (Annissa, 2011) selama tiga kuartal pertama sebelum krisis. Selain itu, tingkat inflasi juga terkendali, sejak tahun 1993 inflasi relatif rendah, yakni antara 4\% hingga 5\% yang menyebabkan penurunan terhadap tingkat suku bunga nominal. Selanjutnya nilai tukar riil juga stabil. Tabungan domestik bruto juga terbilang tinggi melebihi 30\% pada awal tahun 1995 hingga 1996 (Shalendra, 2003).

Kemudian fenomena defisit fiskal tahun 1980-an yang berkisar 2,5\% dari PDB meningkat menjadi surplus pada tahun 1993 dan bertahan hingga awal krisis. Anggaran pemerintah juga hampir seimbang, antara 1990 hingga 1995, defisit transaksi berjalan Korea Selatan yaitu rata-rata $1,9 \%$ dari PDB. Namun, meningkat secara signifikan pada tahun 1996 menjadi 4,7\% dari PDB atau senilai hampir US \$24 miliar (Shalendra, 2003). Defisit transaksi berjalan juga turun menjadi 2,5\% dari PDB, dan pada pertengahan 1997 menjadi sekitar US $\$ 8,2$ miliar atau 1,9\% dari PDB (Shalendra, 2003). Sejak saat ini, gejala krisis ekonomi Korea Selatan mulai muncul.

Berdasarkan data tahun 1997, terdapat beberapa indikator yang menyebabkan perekonomian Korea Selatan menurun dari 8,9\% pada tahun 1995 menjadi 6,8\% pada tahun 1996 (Annissa, 2011). Penurunan ini ditandai dengan defisit anggaran belanja yang sangat besar hingga mencapai US $\$ 15,2$ milyar hanya dalam waktu 8 bulan pertama di tahun 1996. Kondisi ini jumlahnya dua kali lipat dari anggaran pada tahun 1995. Pada kenyataannya defisit mencapai $23,7 \%$ untuk keseluruhan tahun tersebut.

Hal ini semakin ditambah lagi dengan harga komoditi ekspor Korea Selatan yang mengalami penurunan nilai produk petrokimia, baja, dan pembuatan kapal (Annissa, 2011). Nilai ekspor melambat dari 33\% pada tahun 1995 menjadi hanya 3\% pada tahun 1996 (Saito, 1998). Kondisi ini diperparah dengan depresiasi mata uang Yen Jepang. Mata uang Jepang mengalami penurunan sebanyak $17 \%$ pada mata uang Won, sehingga membuat harga barang-barang Korea Selatan menjadi mahal di pasaran Asia Tenggara (Kihwan, 1999). Padahal, harga impor barang yang masuk ke 
Korea Selatan tidak berubah, meskipun volumenya turun sebanyak $11 \%$ sampai pertengahan tahun. Tanda-tanda lain yang menunjukan penurunan ekonomi Korea Selatan adalah meningkatnya hutang luar negeri secara cepat karena deficit perdagangan yang terjadi. Pada tahun 1996, hutang Korea Selatan diperkirakan sekitar US\$100 milliar kepada kreditur internasional (Kihwan, 1999). Hal ini semakin membuat Korea Selatan menjadi negara ketujuh dengan jumlah hutang terbesar.

Beberapa pengamat menyatakan bahwa Korea Selatan terlalu cepat mengembangkan industri di luar negeri dengan bergantung pada sumber pembiayaan hutang (Annissa, 2011). Meskipun utang luar negeri Korea Selatan meningkat secara signifikan pada dekade 1990-an, namun rasio utang per PDB pada tahun 1996 masih hanya $22 \%$, yang berarti masih jauh di bawah tingkat kritis sebesar 48\% yang ditentukan oleh Bank Dunia (Shalendra, 2003).

Menurut Saito (1998), selaku Direktur Regional Office for Asia and the Pacific IMF mengemukakan bahwa sejak tahun 1995 hingga awal tahun 1996 perekonomian Korea Selatan sedang dalam keadaan yang stabil. Posisi laba perusahaan kuat, investasi tinggi, dan kapasitas produktif meningkat. Namun, pada tahun 1996 permintaan eksternal melemah disertai dengan hilangnya daya saing yang dihasilkan dari depresiasi mata uang Yen. Pertumbuhan investasi juga melambat, sebagian mencerminkan ketidakpastian politik yang berlangsung menjelang pemilihan Presiden pada masa pemerintahan Kim Young-Sam. Akibatnya, posisi laba perusahaan mengalami kerugian dan mengalami masalah arus kas, termasuk untuk melunasi hutang yang terakumulasi selama masa booming untuk membiayai investasi yang besar. Ketika pinjaman bank tidak lagi tersedia, beberapa perusahaan Chaebol seperti Hanbo Steel, Jinro, Dianong, New Core Group, dan KIA Motors mengalami kebangkrutan.

Sebagai konsekuensinya, pembayaran kredit terhambat, asetaset perbankan semakin menipis dan neraca perdagangan melemah. Kondisi ini mengurangi kepercayaan kreditur luar negeri yang ragu terhadap bankbank di Korea Selatan sehingga kesulitan untuk mengumpulkan pendanaan baru. Pada saat yang sama, sejumlah bank yang terdiri dari merchant banks, menghadapi masalah likuiditas untuk membayar utang jangka pendek yang akan jatuh tempo. Pemerintah dan Bank of Korea menanggapi masalah ini dengan menyuntikkan dana likuiditas dan memperkenalkan langkah-langkah untuk memfasilitasi 
aliran likuiditas ke perusahaan yang sedang "sakit" tersebut. Pemerintah Korea Selatan juga mengumumkan untuk meningkatkan kepercayaan diri bank yang mengalami defisit. Meskipun demikian, langkah-langkah ini sebagian besar tidak efektif dalam memulihkan kepercayaan kreditur.

Korea Selatan saat ini telah terintegrasi ke dalam sistem pasar global, di mana faktor kepercayaan kreditur memainkan peran penting. Dalam kondisi demikian, respons kebijakan harus berubah, misalnya, menutup bank yang bermasalah. Pada umumnya, kebijakan ini membantu meningkatkan kepercayaan perekonomian dan mampu memfasilitasi pembiayaan eksternal. Namun, tetap saja tidak berkontribusi besar terhadap pemulihan ekonomi Korea Selatan. Melemahnya nilai tukar mata uang Won di pasar saham mencapai angka 10\% (Saito, 1998).

Sebelumnya juga, pada akhir musim panas, pasar keuangan Korea Selatan mengalami kepanikan karena para investor bersiap-siap menarik modal mereka. Hal ini ditambah lagi dengan krisis mata uang di Asia Tenggara yang dialami oleh Thailand dan Indonesia (CNN, 2018). Kondisi ini dapat dimengerti karena sebagian besar produk Korea Selatan di ekspor ke wilayah Asia Tenggara, sehingga kekacauan ekonomi yang terjadi di
Asia Tenggara pasti memberikan dampak yang cukup berarti bagi Korea Selatan (Annissa, 2011, p. 29).

Sebagai respon terhadap kondisi pelemahan ekonomi domestik, Wakil Perdana Menteri Mr. Lim Chang-Yeol mengumumkan bahwa Pemerintah telah meminta dukungan IMF untuk melaksanakan program stabilisasi ekonomi dan reformasi kebijakan struktural. Program ini dibawa ke Dewan Eksekutif IMF dan disetujui pada 4 Desember 1997. Sejak saat itu, pemerintah Korea Selatan mulai memperkuat program tersebut atas pendampingan intensif dari Dewan IMF (Saito, 1998).

Korea Selatan tidak dapat menemukan cara lain untuk keluar dari krisis moneter yang melanda negaranya pada saat itu. Bantuan keuangan IMF senilai US\$57 miliar telah diumumkan oleh pemerintah yang terdiri dari paket darurat pertama berjumlah US $\$ 21$ miliar dan paket tambahan US\$14 miliar yang diberikan oleh Asian development Bank dan World Bank disusul bantuan Amerika Serikat dan Jepang dengan tambahan sebesar US $\$ 23$ miliar. Namun IMF memberikan bantuan keuangan tersebut dengan syarat bahwa Korea Selatan harus melakukan reformasi kebijakan ekonomi. Tujuan utamanya dari program ini adalah untuk menstabilkan nilai tukar dan 
membendung efek inflasi lain dari depresiasi mata uang.

Korea Selatan secara tidak langsung terpaksa harus berhutang kepada IMF dikarenakan kondisi perekomiannya yang terpuruk. Hal tersebut menjadikan IMF mengambil peran dalam menentukan kebijakan ekonomi Korea Selatan. Meskipun demikian, pemerintah Korea Selatan secara perlahan berhasil memulihkan negaranya dari krisis moneter tersebut dengan membayar hutang IMF tiga tahun lebih cepat dari rencana pembayaran yang disepakati. Tidak hanya itu, Pemerintah Korea Selatan juga tidak ingin bergantung pada hutang IMF. Keberhasilan Korea Selatan untuk mengatasi krisis ekonomi nasional mengembalikan citra Korea Selatan sebagai negara yang mandiri (BBC, 2016). Maka dari itu, dalam penelitian ini dijelaskan bagaimana peran IMF di Korea Selatan, apa saja bentuk intervensi yang dilakukan oleh IMF? serta bagaimana strategi Korea Selatan memanfaatkan bantuan IMF memulihkan ekonomi domestik pada tahun 1997?.

\section{TINJAUAN PUSTAKA}

Penelitian tentang strategi Korea Selatan dalam mengatasi keterpurukan ekonomi domestik telah dilakukan oleh beberapa peneliti sebelumnya. Dalam tinjauan pustaka ini, akan disajikan beberapa tinjauan literatur dengan topik tentang Korea Selatan dengan perspektif yang beragam. untuk menemukan strategi apa saja yang telah di lakukan Korea Selatan dalam menuntaskan krisis moneter pada tahun 1997.

Dalam artikel yang ditulis oleh Ririn Darin (2010) yang berjudul "Park Chung-Hee dan Keajaiban Ekonomi Korea Selatan" dijelaskan beberapa kebijakan Park Chung-Hee yang memiliki kontribusi besar dalam perekonomian Korea Selatan. Pemerintahan Park Chung-Hee berusaha merangkul masyarakatnya untuk ikut andil dalam memajukan perekonomian Korea Selatan.

Selanjutnya, dalam artikel tersebut juga dinyatakan bahwa terdapat empat kebijakan pokok Presiden Park Chung-Hee pada masanya. Pertama, kebijakan pembentukan Badan Perencanaan Ekonomi yang bertugas untuk menyusun perencanaan dan tujuan yang ingin dicapai oleh Korea Selatan untuk pembangunan dan pengembangan industri pertanian serta pembangunan ekonomi dan pemerataan pembangunan (Darini, 2010). Kedua, kebijakan ExportOriented Industri (EOI) yang bertujuan untuk mengembangkan perusahaan industri ringan di dalam negeri yang dapat meningkatkan pendapatan 
negara. Ketiga, kebijakan pengembangan industri berat yang bernama Heavy Chemical Industri (HCI). Industri ini meliputi perusahaan produsen mesin-mesin berat, kapal laut, otomotif, petrokimia, dan baja. Keempat, kebijakan modernisasi pedesaan yang bertujuan untuk pemerataan pembanguan daerah pedesaan. Berkembangnya industri tidak sejalan dengan perkembangan pertanian di pedesaan. Sebagai respon, pemerintah Korea Selatan, Park Chung Hee, membuat sebuah gerakan Saemaul Undong yang berarti modernisasi desa yang menghasilkan peningkatan pendapatan petani desa (Darin, 2010).

Tinjauan literatur selanjutnya adalah tesis yang berjudul "Keberhasilan Korea Selatan dalam Mendukung Industri Galangan Kapal sebagai Agenda Meningkatkan Pertumbuhan Ekonomi, Studi Kasus Keberhasilan Hyundai Heavy Industries" yang ditulis oleh M. Zuhaldi Feriawan Wijaya (Wijaya, 2017). Dalam penelitian tersebut, dijabarkan bahwa kebijakan Pemerintah Korea Selatan tentang industri Kapal dari perusahaan Hyundai Heavy Industries (HHI). Perusahaan tersebut menjadi perusahaan kapal terbesar dan tersukses di Korea Selatan dengan permintaan yang selalu meningkat pesat setiap tahunnya ditinjau dari data yang disajikan peneliti. Industri ini turut membantu kemajuan ekonomi Korea Selatan ketika mengalami Krisis Moneter karena sudah berdiri sejak tahun 1970. Sehubungan dengan berdirinya industri tersebut, Korea Selatan akhirnya membuka empat pelabuhan.

Tinjauan selanjutnya adalah bersumber dari tulisan "Financial Crisis in Korea and IMF: Analysis and Perspectives" oleh Lee yang menjelaskan tentang penyebab krisis moneter di Korea Selatan tahun 1997. Menurut Lee (1998), pada dasarnya pemerintah Korea Selatan sangat anti IMF mengingat dampak pinjaman IMF sangat mengerikan terhadap pertumbuhan ekonomi suatu negara. Ada pun penjelasan Lee bisa diringkas menjadi empat dampak pahit IMF bagi Korea Selatan yang meliputi beban suku bunga tinggi yang mencapai 30\%. Konsekuensinya, Korea Selatan menghadapi persoalan antara lain, peningkatan beban hutang, krisis mata uang, pemutusan hubungan kerja (PHK) secara besar-besaran karena perusahaan sudah tidak menerima dana dari bank, dan yang terakhir adalah untested presiden (Lee, 1998).

Tinjauan selanjutnya berdasarkan jurnal yang berjudul "The South Korean Crisis of 1997 and its Aftermath: The Legacy of the Developmental State and the Importance of State capacity in Post-Crisis Adjustment" yang ditulis oleh M. 
Mustafa Erdogu. Dalam jurnal tersebut terdapat tiga pembahasan utama. Pertama, Erdogu meneliti dan berusaha membuktikan argumennya tentang sejauh mana perkembangan Korea Selatan sebagai penyebab krisis ekonomi Asia. Kedua, digunakannya perspektif kritis tentang peran IMF dalam dan pasca krisis moneter yang terjadi tahun 1997. Ketiga, perhatian difokuskan pada dinamika yang mendasari proses pemulihan Asia era pasca-krisis di Korea Selatan.

Penyebab terjadinya krisis adalah liberalisasi keuangan yang tidak terkendali. Krisis 1997 sebagian besar disebabkan karena liberalisasi pasar dan arus modal yang mengarah pada ketergantungan berlebihan terhadap sektor swasta. Pada tahun 1997, pemerintah Korea Selatan tidak dapat menemukan cara untuk keluar dari krisis moneter yang melanda negaranya, sehingga memaksa pemerintah menerapkan program darurat dari IMF pada November 1997 (Sohn, t.t).

Pada awal 1998, pemerintahan Kim Dae-jung yang baru terpilih mulai mereformasi sektor keuangan yang tidak efisien dengan menggunakan empat pendekatan (Sohn, t.t). Pertama pemerintah harus menutup atau menggabungkan lembaga keuangan yang bangkrut dan memperkuat basis modal "Viabel Ones" yang membutuhkan penghapusan nonperforming loans pada lembaga terkait dan rekapitalisasi lembaga keuangan melalui Public Funds maupun investasi luar negeri. Kedua, sistem regulasi perlu direformasi agar menciptakan transparansi dan akuntabilitas. Ketiga, deregularisasi berkelanjutan dan liberalisasi pada pasar keuangan diperlukan untuk mendukung investasi asing dan menunjukkan komitmen untuk mereformasi finansial. Terakhir, pemerintah harus mengembangkan kapasitas kelembagaan untuk melakukan reformasi ini (Mo, t.t).

Beberapa laporan menunjukkan bahwa krisis keuangan Korea Selatan pada tahun 1997 merupakan akibat dari masalah struktural yang membuat neraca lembaga keuangannya rentan terhadap guncangan eksternal. Kerentanan keuangan patut mendapat perhatian khusus, karena pemerintah Korea Selatan mengusahakan strategi pertumbuhan yang tinggi untuk meminimalisir lemahnya pengawasan keuangan dalam negeri. Oleh karena itu, langkah-langkah reformasi harus dilakukan di seluruh sektor keuangan dan perusahaan secara bersamaan. Restrukturisasi ini sangat penting karena perusahaan yang bangkrut adalah sumber masalah keuangan di Korea Selatan. 


\section{METODE PENELITIAN}

Penelitian ini menggunakan metode kualitatif dengan sifat deduktif yang menjelaskan strategi Korea Selatan dalam pemulihan krisis moneter tahun 1997 yang difokuskan pada peran IMF sebagai institusi keuangan internasional.

Pengumpulan data diperoleh melalui studi pustaka, yaitu observasi literatur dari berbagai sumber seperti buku dan jurnal sebagai data primer, dan artikel maupun berita yang relevan.

\section{KERANGKA TEORITIK}

Dalam penelitian ini digunakan teori Liberalisme Institusional yang memandang bahwa keberadaan organisasi internasional dalam kerjasama antar negara dapat berperan sebagai instrumen perdamaian dan mencegah terjadinya konflik sekaligus berperan dalam mengatasi masalah ekonomi, gender, agama, dan HAM.

Teori Liberalisme Institusional menolak untuk dikatakan sebagai alat negara-negara besar untuk mengintervensi negara lain. Teori ini memiliki argumen bahwa organisasi internasional sepenuhnya berperan secara independen dalam membantu negara-negara untuk saling bekerjasama dalam sektor militer, social, politik maupun ekonomi (Jackson \& Sorensen, 2013).
Organisasi internasional bersifat otonom yang berarti bahwa institusi internasional memiliki kewenangan atau kedaulatan untuk mengubah kebijakannya sendiri tanpa adanya intervensi dari negara lain (Goldstein \& Keohane, 1993). Kelompok liberalisme institusional berargumen bahwa keberadaan organisasi maupun institusi internasional bisa mengatasi anarki yang diakibatkan oleh minimnya kepercayaan negara satu dengan yang lain. Pasalnya, sebuah institusi internasional bisa menambah kepercayaan antara negara satu dan yang lainnya dengan cara membuka forum untuk negosiasi antarnegara. Organisasi maupun institusi internasional dinilai Keohane menciptakan stabilitas kawasan dan menciptakan iklim yang damai (Jackson \& Sorensen, 2013).

Sejak dua puluh tahun pasca Perang Dunia II, kelompok liberalisme institutional mulai memikirkan bahwa strategi untuk menciptakan stabilitas keamanan bukan hanya berpusat pada militer dan politik, tetapi juga bidang ekonomi. Teori ini mulai meluas ke bidang lain, bahwa negara-negara perlu untuk melakukan perdagangan internasional yang kemudian menciptakan ketergantungan antar negara (Goldstein \& Keohane, 1993).

Meskipun demikian, ketergantungan atau interdependensi 
bidang ekonomi menurut Keohane dan Goldstein (1993) dapat menimbulkan kompleksitas jika terjadi perubahan tidak terduga dari suatu negara terhadap negara lain. Misalnya saja ketika terjadi devaluasi yang terjadi pada negara lain akan memunculkan masalah baru bagi negara yang memiliki hubungan secara ekonomi atau yang disebut sebagai efek domino (Farlex, t.t).

Teori liberalisme institusional percaya bahwa kehadiran institusi internasional bisa menghindarkan perselisihan dan mengharmonisasikan hubungan antargara. Untuk mewujudkan kerjasama yang baik dengan menyelaraskan kebijakan masing-masing negara, maka institusi internasional akan mengelola kebijakan dari negara lain agar kompatibel satu sama lain dan agar dapat diterima secara luas (Goldstein \& Keohane, 1993). Dalam buku yang ditulis oleh Keohane dan Goldstein (1993), Amerika Serikat selama Perang Dunia II merupakan pemegang kekuatan hegemonik dalam tatanan ekonomi politik internasional, hampir seluruh negara-negara di dunia memerlukan keterlibatan Amerika Serikat.

\section{HASIL DAN PEMBAHASAN}

\section{Peran IMF di Korea Selatan}

Korea Selatan merupakan salah satu negara yang mendapatkan pinjaman dana dari International Monetary Fund (IMF) ketika terjadi krisis moneter tahun 1997. Pinjaman tersebut benilai US $\$ 40$ miliar. Walaupun Korea Selatan adalah negara yang mandiri, tetapi krisis moneter berakibat pada kemunduran ekonomi yang cukup signifikan (Callahan, 2004). Sebagai contoh, perusahaan otomotif KIA Motors mengalami jatuhnya pasar saham dan mengalami kerugian yang besar. Hal itu mendorong Korea Selatan untuk melakukan penyesuaian terhadap kebijakan pasar, finansial, dan perdagangan.

Oleh karena itu, keberadaan dan peran IMF dinilai sangat membantu negara-negara yang sedang mengalami krisis ekonomi seperti Korea Selatan pada tahun 1997. Peran IMF dinilai efektif dalam mengatasi permasalahan krisis moneter di Korea Selatan. Hal ini ditandai dengan bangkitnya perekonomian Korea Selatan yang lebih cepat dari negara-negara Asia lainnya.

\section{Intervensi IMF dalam Krisis Moneter Korea Selatan}

Alasan IMF untuk membantu mengatasi krisis ekonomi Korea 
Selatan juga didorong oleh tujuan untuk menjaga stabilitas ekonomipolitik internasional. Dengan menggunakan sistem nilai tukar dan pembayaran internasional yang lebih terbuka dapat meningkatkan penyebarluasan arus modal antarnegara. Dalam aspek pengawasan, IMF memengaruhi kebijakan negara-negara anggota untuk dapat meningkatkan stabilitas ekonomi di negaranya. Sehingga, dapat mengurangi kemungkinan krisis ekonomi di kemudian hari.

IMF menawarkan pinjaman terbesar US\$58 milliar kepada Korea Selatan dari semua negara di Asia Timur dengan berbagai persyaratan. Salah satunya adalah reformasi yang mendasar dari sektor ekonomi, seperti kebijakan fiskal yang ketat, neraca modal, dan liberalisasi perdagangan serta reformasi pasar tenaga kerja (Williamson, 2012; Shin, 2002, p. 98). IMF pun memiliki tujuan untuk memberikan pinjaman kepada Korea Selatan dikarenakan potensi Korea Selatan sebagai negara kesebelas dengan ekonomi terbesar di dunia dalam sistem moneter internasional. Intervensi IMF terhadap Korea Selatan juga merupakan upaya untuk menyebarluaskan model liberalisme ekonomi barat.

\section{IMF dan Liberalisme Institusional}

Kaum liberalis memandang bahwa keberadaan institusi internasional seperti IMF dapat membuat tatanan dunia menjadi teratur dan damai. Hal ini didasari keyakinan bahwa institusi internasional mempunyai peran untuk memajukan kerjasama antarnegara (Keohane 1989; Acharya dan Johnston, 2007) sekaligus penyangga dalam mengatasi permasalahan di dalam suatu negara maupun antarnegara dalam lingkup global.

Dengan adanya institusi
internasional,
institusional percaya bahwa hal ini dapat dapat mengurangi kekacauan dan anarki dalam sistem internasional. Dalam hal tersebut, anarki yang dimaksud adalah hanya ada sedikit ruang bagi kepercayaan antara negara serta hanya negara tersebut yang dapat menjamin keberlangsungan hidupnya sendiri (Mearsheimer, 1993, p. 148).

Meskipun demikian, Korea Selatan juga meyakini adanya sistem anarki dalam kondisi krisis moneter yang dialaminya. Didukung kondisi Korea Selatan sebagai negara yang pernah mengalami perekonomian pesat sebelum terjadi krisis moneter, timbul kekhawatiran lesunya perekonomian Korea Selatan justru dapat mengarah kepada gejolak politik dalam negara ginseng tersebut. Hal 
tersebut juga dapat memicu adanya konflik yang berpotensi mengancam stabilitas domestik Korea Selatan dan negara-negara lain dalam tatanan internasional. Sehingga, institusi internasional dianggap sebagai sebuah harapan untuk menciptakan perdamaian dunia.

IMF memiliki fungsi dalam mengatasi krisis moneter di negaranegara, termasuk di Korea Selatan. Fungsi pertama adalah sebagai penyedia pinjaman dana bagi negara anggota IMF. Kedua, memberikan saran kebijakan dalam suatu negara yang terkena krisis moneter. Ketiga, mengatur dana bantuan bagi negara berkembang dengan tujuan untuk mencapai stabilitas ekonomi makro dan menurunkan tingkat kemiskinan (Lauren, 2014). IMF juga menyediakan pembelanjaan bagi negara anggota dalam rangka melakukan reformasi struktural negara anggota (IMF, 2003).

\section{Strategi Korea Selatan melalui IMF}

Korea Selatan memanfaatkan IMF untuk mendirikan perusahaan Multi National Coorperation (MNC) seperti Samsung (Purba dan Suzana 2015). Hal tersebut merupakan salah satu strategi Korea Selatan untuk dapat mengembalikan stabilitas ekonomi domestik. Dengan adanya perusahaan MNC tersebut dapat mendorong adanya kegiatan ekspor ke negara- negara lain, seperti Cina dan India sekaligus meningkatkan pendapatan bagi Korea Selatan.

Jika dibandingkan dengan negara Asia Tenggara, seperti Thailand dan Indonesia, pemulihan ekonomi Korea Selatan pulih lebih cepat dari negaranegara lain yang juga mengalami krisis moneter tahun 1997. Bahkan, pembayaran hutang Korea Selatan sejumlah 58 milliar US Dollar kepada IMF dapat lunas dalam jangka waktu tiga tahun lebih cepat dari yang disepakati antara Korea Selatan dan IMF. Hal tersebut mengembalikan citra Korea Selatan yang merupakan negara yang mandiri (Ririn, 2010).

Reformasi ekonomi yang dilakukan oleh Kim Dae-Jung sebagai Presiden Korea Selatan periode tahun 1998-2003 ditandai dengan program liberalisasi pasar keuangan untuk memperkuat arus modal investasi asing secara terbuka. Oleh karena itu, intervensi IMF dalam kebangkitan dari perekonomian Korea Selatan dianggap cukup efektif dalam membantu krisis moneter tahun 1997 bagi negaranya. Tentunya, tidak hanya bantuan dana dari IMF, tetapi etos kerja dari Pemerintahan Korea Selatan dan adanya kerja sama Perusahaan MNC Korea Selatan (Ririn, 2010). 


\section{KESIMPULAN}

Hubungan antara Korea Selatan dan IMF tidak lepas dari kepentingan nasional untuk memperoleh pinjaman dana oleh IMF dan beberapa negara lain senilai US $\$ 57$ miliar. Meskipun demikian, pinjaman yang diperoleh Korea Selatan dari IMF mensyaratkan perlunya reformasi ekonomi dalam kebijakan fiskal, neraca modal, dan liberalisasi perdagangan, dan pasar tenaga kerja. IMF pun memiliki tujuan untuk memberikan pinjaman dana terhadap Korea Selatan tersebut, dikarenakan terdapat potensi Korea Selatan sebagai negara ke sebelas ekonomi terbesar di dunia dalam sistem moneter Internasional. Hal itu dikarenakan kekhawatiran IMF bahwa perekonomian Korea Selatan dapat bersaing ketat dengan perekonomian negara Barat. Sehingga, secara tidak langsung IMF menginginkan Korea Selatan untuk melakukan liberalisasi ekonomi seperti sistem ekonomi di Barat.

Prinsip liberalisme institusional yang ada pada IMF merupakan hal yang penting dan fundamental. Kaum liberalisme institusional berpendapat bahwa tingkat institusional yang tinggi dapat mengurangi dampak kekacauan yang mengarah pada anarki. Korea Selatan pun meyakini adanya sistem anarki dalam kondisi krisis moneter tersebut. Didukung kondisi Korea sebagai negara yang pernah mengalami perekonomian pesat sebelum terjadi krisis moneter, timbul kekhawatiran lesunya perekonomian Korea Selatan yang dapat mengarah kepada kondisi politik dalam negara. Hal tersebut pula dapat memicu adanya konflik yang dapat mengancam stabilitas Korea Selatan dan negara-negara di dunia.

Keberadaan institusi interanasional seperti IMF dianggap sebagai sebuah harapan untuk mencapai perdamaian dalam lingkup global. IMF memiliki fungsi dalam mengatasi krisis moneter di negaranegara, termasuk di Korea Selatan. Dalam memamfaatkan kehadiran IMF, Korea Selatan mendirikan perusahaan Multi National Coorperation (MNC), seperti perusahaan elektronik, salah satunya adalah produk Samsung yang merupakan salah satu produk elektronik terlaris di dunia. Sehingga mampu mendorong ekspor yang lesu di Korea Selatan.

Selanjutnya, liberalisasi pada pasar keuangan yang bertujuan untuk mendukung adanya investasi asing yang semula menarik diri, serta mereformasi finansial dari Korea Selatan. Dengan starategi ini, Korea Selatan mengalami kebangkitan ditandai dengan kondisi ekonomi yang pulih lebih cepat dari negara-negara terdampak krisis moneter terparah yaitu Indonesia dan Thailand. Bahkan, pembayaran hutang Korea Selatan 
sejumlah US\$57 miliar kepada IMF dapat terlunasi dalam tiga tahun lebih cepat dari yang disepakati oleh kedua belah pihak.

\section{REFERENSI}

Annissa, Jeanie. (2011) 'Faktor-Faktor Penyebab Krisis Ekonomi Di Korea Selatan Periode 1997-1998', Transnasional Jurnal Ilmu Hubungan Internasional, Vol.6, No.1, pp. 27-33.

BBC News. (2016) Krisis Politik Korea Selatan, Rakyat Cari Kesempatan Baru (Online). Tersedia di: https://www.bbc.com/indonesia/dun ia-38145298 (Diakses: 26 Maret 2019).

Darini, R. (2010) 'Park Chung-Hee dan Keajaiban Ekonomi Korea Selatan', Vol. 5 No. 1 (Online) Tersedia di: https://doi.org/10.21831/moz.v5i1.4 336 (Diakses: 5 Maret 2019).

Farlex. (t.t) Domino Effect [online]. Tersedia di: https://www.thefreedictionary.com/d omino+effect (Diakses: 5 Maret 2019).

Fernandez, M. \& Irene. (2015) Korea and the Asian Economic Crisis: Did Korea Change its Economic Model?. Barcelona:

Universitat de Barcelona.

Goldstein, J. \& Keohane, R. O. (1993) Ideas and Foreign Policy Beliefs, Institutions, and Political Change. New York: Cornell University Press.

Hennida, Citra (et.al) (2016) 'Budaya dan Pembangunan Ekonomi di Jepang, Korea Selatan, dan China', Journal Global \& Strategis (Online). Vol. 10 No. 2. Tersedia di: http://dx.doi.org/10.20473/jgs.10.2.2 016.248-263 (Diakses: 5 Maret 2019).

IMF. (2017) Sekilas tentang IMF (Online). Tersedia di: https://www.wwf.org (Diakses: 5 Maret 2019).

Jackson, R. \& Sorensen, G. (2013) Introduction to International Relations:
Theories and Approaches. United Kingdom: Oxford University Press.

Kim K. (2000) The Korean Financial Crisis: Causes, Response and Lessons in Bisignano J.R., Hunter W.C., Kaufman G.G. (eds) Global Financial Crises. Boston: Springer.

Lavinda. (2018) Baht, Peluit Krisis Mata Uang Asia (Online). Tersedia di: https://www.cnnindonesia.com/ekon omi/20180502033958-532-

294984/baht-peluit-krisis-mata-uangasia (Diakses: 7 April 2019).

Moon, Chung-In, \& Mo, Jongryn. (2000) Economic Crisis and Structural Reforms in South Korea. Economic Strategy Institute.

Purba, T. S. dan Afrizal (2015) 'Strategi Ekonomi Politik Samsung Group Company Dalam Menguasai Pasar Seluler Smartphone di Indonesia', Vol. 2 No. 2 (Online). Tersedia di: https://jom.unri.ac.id/index.php/JO MFSIP/article/view/7297/6975 (Diakses: 5 Maret 2019).

Rodier, L. (2014) 'Assessing the Role of the IMF in South Korea during the Asian Financial Crisis', Journal of Economics and Development Studies, Vol. 2, No. 2.

Saito, K. (1998) Korea's Economic Adjustments Under the IMF-supported Program Presentation by Kunio Saito (Online). Tersedia di: https://www.imf.org/en/News/Artic les/2015/09/28/04/53/sp012198a (Diakses: 7 April 2019).

Sharma, Shalendra D. (2003) 'Review Essay: Chaebols and the Korean Financial Crisis', Indian Journal of Asian Affairs, Vol. 16, No. 1/2, pp.159-168.

VOA News. (2001) Korea Selatan Lunasi Hutang IMF Lebih Cepat (Online). Tersedia di: https://www.voaindonesia.com/amp /53417.html (Diakses: 25 Maret 2019). 